epiphany

Journal of the Faculty of Arts and Social Sciences

International University of Sarajevo

ISSN 1840-3719 / No. 3 - Special Issue: Identity

Fall 2009

\title{
Charlotte Perkins Gilman's Re-Creation of Masculinity
}

\section{Gamze Sabancı \\ Haliç University}

In her 1903 study The Home: Its Work and Influence, Gilman considers the effect of the concept "the home" on both men and women. She explores how established norms and traditions inform society's views of the abilities and appropriate behaviors for each sex. As Gilman points out, beliefs about what a man ought to do have a direct effect on what a woman is allowed to do: changes to established practice are regarded as threats to the social roles of "man" or "woman." She sums up the argument by saying that "man considers any effort of the woman to support herself as a reflection on him" (Home 290). Gilman was aware of the need to include men in her proposals for improving society, in order to achieve lasting reform. Thus, to gain the sympathy of her male readers, Gilman shows that a working wife is not the threat traditional opinion held, but rather a comfort to her husband. Having asserted this in works such as The Home, Gilman deliberately adapts her fictional writing to her political writing and her audience by using a wide range of genre in her work including autobiography, treatise, lecture, short story, fable, novel and poetry. She expresses similar things in habitually different ways by using different language to persuade people. A short story written to reinforce shared ideas and motivate a self-selecting and already-convinced readership (such as Gilman had for her Forerunner publications) does not need to explain in detail the basis of the assumption and views shared with that readership. Instead it can assert and then expand, creating inspiring scenarios to encourage continued efforts 
at reform, without too much concern about how credible or detailed each scenario is. Characters may be less rounded and complex in a short story than in a full novel, with stories that are in effect fables being able to get away with the lightest characterization of all. A lecture must carry a slightly different audience. Again selfselecting, because that the audience has chosen and indeed paid to hear what is said, but they may not share quite the same level of conviction as the speaker. The message here must be clear, effective and probably stirring - and this is true when that lecture is delivered on paper as well as orally. As with longer non-fictional pieces, the book-length treatises Gilman wrote, there is room for anecdote and illustrative, imagined stories, but these are typically very simple, often humorous and with a clear point. Books, even one as short as Man-Made World, need to justify their length and address an entirely open readership. The writer cannot be sure of shared views and must also explain and support arguments more fully. Points need to be developed, arguments expanded upon, other views taken into consideration. Although Gilman's textual strategies differ in different genres, her motto remains the same: offering role models for both sexes and creating stories in which women become powerful for their own sake, though their empowerment often benefits a man. The stories discussed here, "Her Housekeeper" and "The Cottagette", both published in 1910, approach the topic of the conflict between marriage and freedom, particularly freedom to work, through two very different scenarios. In "The Cottagette" Gilman presents the case of Malda, a young woman who is attracted to Ford, a journalist she meets while at an artists' retreat. In "Her Housekeeper" she tells the story of an older woman, Mrs. Leland, who has a young son but no husband, but who prizes her independence and so resists a marriage proposal from her good friend, Arthur Olmstead, who lives in the same boarding house as Mrs. Leland. Underpinning both stories is Gilman's belief, as stated in The Home, that a 
woman should work not just to gain independence or to share the financial expenses of the home (which should remain the responsibility of the man of the house) but also to create a happy atmosphere within her home and thus become a positive influence on her husband and as well as any children she may have. A woman achieves such success and happiness by satisfying her need to pursue her own artistic passion - a passion Gilman seems to presume exists in every woman and which is exemplified in "The Cottagette" by Malda's skill in drawing and embroidery, and in "Her Housekeeper" by Mrs. Leland's successful acting career. However, Gilman was not only recreating femininity, by providing fictional examples of cultural evolution in United States homes. By including men in this development, and creating male characters who actively want their wives to continue with their artistic work after marriage, she was also presenting methods of recreating masculinity without undermining men's sense of security and re-evaluating the representations of masculinity.

Attempts to transform gender relations in the nineteenth century usually also challenged prevailing definitions of masculinity and femininity. In "The History of Masculinity" R. W. Connell reasons:

The nineteenth century saw a historic change in gender politics, the emergence of feminism as a form of mass politics - a mobilization for women's rights, especially the suffrage, in public arenas. This was closely connected to the growth of the liberal state and its reliance on concepts of citizenship (249).

When social conditions altered for women and for men, as women started fighting for economic independence, the clear division between gender roles became blurred. The new class of working women unsettled "masculinity" as well as challenging ideas of what a proper woman ought to be and do. Michael Kimmel 
(1987) has classified men's responses to this change into three groups. Firstly "an antifeminist response," which "demanded women's return to the private sphere of hearth and home." Secondly, a "masculinist response," which "sought to dislodge women's control over the private realm", while creating separate places where men could practice the "hardiness appropriate to their gender". This self- serving group held the almost sacred belief that masculinity could only be understood and practiced by men and thus men should be more engaged with bringing up young boys at home. This has the effect of requiring more active fatherhood which takes a positive role in domestic life, as a means of counterbalancing an over feminine domestic atmosphere. Thirdly, a "profeminist response" which Kimmel describes as coming from a small but vocal group who supported feminist reforms, including "demands for sexual autonomy for women and men" (Kimmel 262). As this discussion will show, Arthur Olmstead and Ford Mathews embody elements of Kimmel's second and third categories, while the first is reflected in Gilman's plotlines as a whole.

There is much common ground between Gilman and the men of Kimmel's second category. The eagerness of the "masculinist response" to be involved in child education is based on a fear of homosexuality. As Kimmel summarizes, "If they [boys and girls] mingled, boys would become feminized and hence, homosexual" (270). Although not explicitly homophobic, Gilman's social philosophy is based on similar ideas. In her essay on "Kitchen- Mindedness" she critically writes that "Children are brought up by their mothers in the kitchen" (195). This criticism is twofold. One is the fact that Gilman criticizes the tradition that bringing up children in the kitchen by mothers who have no other special occupation and talent and claims that it is an endless circle without a beginning and an end. The second reason is hidden behind this first reason but still visible when applied to Gilman's 
short stories. Gilman is not only aiming to relieve women from domestic chores, but she also implies that kitchen education is more dangerous to boys than girls, so especially boys should not be solely educated by their mothers but also their father's participation is of great importance for the sake of their masculinity. In the light of this one might suggest that the reason there are no baby boys in Herland, is because there are no men to teach manliness to the boys. In "Her Housekeeper" we see Gilman counteract the dangers of too feminine an upbringing by providing Johnny with a father figure in Arthur Olmstead. At the same time she was very careful not to feminize him, despite designating him "her housekeeper" and so aligning him with a domestic occupation. As we will see, Arthur is a character who thus typifies the masculinist response, but is essentially a profeminist man.

As stated, this third group of Kimmel's, the "profeminists" who "support[ed] women's public participation in general" ("Men's Response" 262) believed that men also suffered from the effects of women's oppression and so would benefit from their liberation. Kimmel cites H. L. Mencken's essay "In Defense of Women" (1918) as an example of this attitude, quoting him as saying "Neither sex, without some fertilization by the complementary characters of the other, is capable of the highest reaches of human endeavor." ("Men's Response" 273). There is a clear correspondence between this profeminist response and Gilman's views as expressed in The Home:

The influence of women upon men is enormous. The home- bound mother limits the child and boy; the home- bound girl limits the youth; the home- bound wife keeps up the pressure for life. It is not that women are really smaller- minded, weaker- minded, more timid and vacillating; but that whosoever, man or woman, lives always in a small dark place, is always guarded, protected, directed, and restrained, will become inevitably narrowed and weakened by it. The woman is narrowed by the home and the man is narrowed by the woman. (277) 
Gilman's remedy for this situation is that women should improve themselves, as this improvement will be beneficial for all around her, the child and the husband. The narrowing and weakening dangers of over-domestication is clearly portrayed in "The Cottagette" where the male character Ford Mathews initially makes it a condition of marriage that Malda gives up housework, as she is changed by such domestic responsibilities that prevent her from doing her own "lovely work" (137), which she previously found so fulfilling.

The responses to feminism outlined above differed, collectively they reveal a common belief that masculinity was in crisis. In another essay, Michael Kimmel explains, "Masculinity was something that had to be constantly demonstrated, the attainment of which was forever in question-lest the man be undone by a perception of being too feminine. Masculinity required proof, and proof required serious effort" (Manhood 120). For some, the proof meant football or boxing, but for Gilman in her fiction the proof is less physical but more verbal: men still have the last say.

In Man-Made World, Charlotte Perkins Gilman indicated a similar understanding of such enactments of masculinity when she suggested that "basic masculine characteristics: desire, combat, self- expression [are] all legitimate and right in proper use, only mischievous when excessive or out of place" (Man-Made 41). Hence, in her short fiction she created male characters accordingly; the men we are to admire are able to distinguish when it is "proper" to exhibit traditional male character traits, and when it is better, more proper, to prove their masculinity by acting in a different way, a way which might not previously have been called masculine, or by simply accepting and supporting the actions of their womenfolk. As a result, Gilman redefines the understanding of masculinity by moving its values 
away from traditional and patriarchal definitions, towards a new construction of maleness. This reconstructed masculinity became vitally important for Gilman's arguments that if the opposite sexes were to complement, they needed to find ways to develop equally. Fiction was an effective vehicle for presenting the value of such reconstruction, and at the same time, this ideology offered fiction a new subject.

The man himself, in this new association, offers another subject refreshingly novel. Man married to reason as well as love; man befriended instead of waited on; met by cheerful intelligence, a wise good will, an affection that has understanding; instead of helpless innocence, pathetic dependence, and all the dragging selfishness of the pretty, greedy childish thing, who is one of the by-products of the woman's false position... The freedom and happiness of men, when mothered, sistered and wived by adequate normal women, is itself a subject to occupy many pens for many years. ("Coming Changes" 131)

Gilman believed that literature mirrors life ("Coming Changes" 125): up to now, the world was man's, therefore "All previous literature has been androcentric; written by men for men, by men to please their women, or by their women to please men" ("Coming Changes" 125). Thus, women's taking an active place in the world should be reflected in the literature: "we shall begin to look at women as persons, and measure them in relation to other persons, and to the world at large" ("Coming Changes" 125). What is more, in Gilman's view man's need of an equal partner and how he would also benefit from the change womanhood is going through, is the truth of life and so should also be reflected in literature. Gilman's emphasize is thus on the relationship between the men and the women in their reconstructed environment and how their characters are affected by these changes. "Her Housekeeper" and "The Cottagette," both exemplify Gilman's characterization of New Men, and how they might contribute directly to the necessary reform of society and social views. At the same time her characters show how masculinist elements 
can be found in even the most overt profeminist.

The men presented as admirable in Gilman's stories are often instrumental in ensuring that the central female characters achieve the state of happy fulfillment that Gilman argued was so necessary for creating a constructive and healthy home and society. Chief among such characters is Arthur Olmstead in "Her Housekeeper" (January 1910), whom Gilman presents as willing to take on all housekeeping responsibilities, regardless of traditional expectations, so that the woman he admires as an actress can continue with her career even when married to him. Carol Farley Kessler labels Arthur Gilman's "model feminist partner" (59), who does not expect his wife to be solely responsible for domestic chores or child care, while Beth Sutton-Ramspeck argues that in this story Gilman demonstrates that housekeeping is "redefined as limited to neither the private sphere nor the female sex" (8). However, I argue that Gilman maintains Arthur's traditional masculinity by explaining to readers that his housekeeping is a practical business, rather than a domestic role, and by pointing out that in this allegedly ideal household it is still women (the maid, the cook and the governess) who actually perform the necessary domestic chores. These duties may be removed from middle-class women, but rather than being undertaken by or shared with men, they are placed instead on the shoulders of lower-class women. "Her Housekeeper" exemplifies Gilman elevating housekeeping to a business when overseen by a man, while still regarding the actual housework tasks as low-grade, and to be undertaken by women. This redefinition of role implicitly indicates Gilman's refusal to feminize her New Man.'

Seven months later Gilman created Ford Mathews in "The Cottagette" (August 1910), whom Catherine Golden considers “Gilman's most liberated New Man" (131). This echoes the apparent admiration with which Gilman concludes this story: "Was there ever a man like this?" (138). Gilman's rhetorical question praises 
Ford Mathews for insisting that his fiancée Malda give up her stint at cooking and resume her artwork. No matter that Gilman creates Ford Mathews as a liberal, intellectual and male character who diverges from her thoroughly patriarchal males, I will argue that Ford Mathews is still similar to the majority of men in Gilman's stories in one important respect: he insists upon having the last word. In doing so he thoughtlessly exerts his influence over Malda, though he is not a hostile bully. Indeed he quickly withdraws the condition of marriage he at first imposes, but the fact that he feels he can state conditions at all reveals how much Ford has become Malda's "immediate and all-important environment" (Women and Economics 61). The relationship between Ford and Malda exemplifies how much the presentation of attraction between a man and woman affects our very understanding of the interaction between them. "The Cottagette," in offering us a romance leading to marriage, exemplifies how presenting sex relations with "flowers and incense and all accumulated sentiment" (Women and Economics 63) allows us to see such a marriage as right, lovely and, most importantly, equal. However, if we look below such surface sentiments we find traces of "the transient [sex] trade we think evil" (Women and Economics 63), a reality that made Gilman uneasy about the institution of marriage, even though she also endorsed it. By focusing on aspects first of "Her Housekeeper" and then of "The Cottagette" that illuminate contradictions in Gilman's attitude toward financial independence for women and toward women's expected domestic role, this essay will show how Arthur Olmstead and Ford Mathews are examples of New Men who are also, I suggest, in the end as conventional as other males in her oeuvre.

In "Her Housekeeper" Gilman created a female character, Mrs. Leland, whose profession as an actress makes her a public figure. Added to this, she is the sole wage-earner in her little household, which consists of herself, her son and his 
nurse/governess. As such, Mrs. Leland is clearly occupied with the public sphere. Arthur Olmstead, in contrast, is occupied with the private sphere because although he is, as Mrs. Leland understands, a businessman, in real estate, it transpires that his business is house letting and that he both owns and runs the boarding house in which Mrs. Leland herself lives. Arthur is thus as fully occupied with the private sphere as Mrs. Leland is with the public. By doing this Gilman responds to masculinists suggesting that masculinity will not fall into crisis, just because men become more involved with domesticity. Rather, by the end of the story, not only does Gilman redefine gender roles, but also manages to redefine marriage to the benefit of all concerned. Mrs. Leland gains a companion and housekeeper, Arthur is able to marry the woman he loves and to have her continue to be the woman he admires, and Johnny gains a father who takes an active interest in him and his education.

Enjoying her career as an actress, as well as the freedom it permits, "widow, not divorcee" (Kessler 147) Mrs. Leland ${ }^{2}$, considers marriage a threat to both. "I hate - I'd like to write a dozen tragic plays to show how much I hate Housekeeping!"(153) she cries out to Arthur Olmstead, who is a resident and also, unknown to her, the owner of the boarding house where she lives. He is able to persuade her to marry him, only after refuting all six of her reasons why she doesn't want to marry, not the least of which are the housewifely duties which give rise to the cry quoted above. Only when Arthur has removed or refuted all her objections does Mrs. Leland marry "Her Housekeeper." Through this simple plot Gilman perpetuates the notion that what women really want is marriage, if it can be achieved on their terms. Gilman advises women that-

We are slowly forming a nobler type of family; the union of two, based on love and recognized by law, maintained because of its happiness and use. . . It 
will be good for all the parties concerned-man, woman and child; and promote our general social progress admirably (Man-Made World 50).

By successfully turning a situation to their benefit, women can put themselves in a position to make decisions that do not require them to sacrifice their own personal pleasures. Gilman here presents an independent woman whose lover does not require her to marry, yet who would apparently rather be married than not. In "Her Housekeeper" Gilman shows that the fault lies not with women, but with marriage as an institution. Unless that institution is reformed, intelligent women will stop agreeing to marry and society will collapse. By having Arthur agree that traditional marriage is just a form of imprisonment that forces women to give up their careers and by having him object to this as much as her, Gilman shows that a New Man will be aware of women's marital tribulations, appreciative of their fear, and ready to reform marriage for the good of all.

Just as Arthur represents the New Man, so in many ways Mrs. Leland fits Gilman's description of the New Woman. She is strong, energetic and economically productive, yet she is also very feminine, attracting the attention of many men while also, importantly, being a mother. For Gilman, women's femininity and men's masculinity is very important. She puts extra emphasis on the fact that when a woman is involved in the public sphere, which is supposed to be the man's world, and a man is involved in the private sphere, supposedly the woman's world, it does not make either of them less feminine or less masculine. Responding to the social fear of masculinity being in crisis and femininity being erased by the kinds of reform she sought, Gilman asserted that:

Our error lies in a false estimate of womanhood and manhood. The home, its labours, cares and limitations we have called womanly; and everything 
else in life manly. ... This is entirely wrong. (Home 280)

Arthur Olmstead is a hero who is successful in the traditionally male terms of being financially secure and able to provide for a wife, but he is also a reformist hero in his challenge to separate spheres and refusal to act like a tradition male:

He seemed to make all the money he needed, occupied the two rooms and plentiful closet space of his floor in great contentment, and manifested most improper domesticity of taste by inviting friends to tea. "Just like a woman!" Mrs. Leland told him (Kessler 149).

As Monika Elbert observes, Mrs. Leland is aware throughout the story that Arthur is sensitive and nurturing and it is these qualities, contrasted with Mrs. Leland's desire to retain her career and freedom from domestic drudgery, that leads Elbert to state that "the whole story offers a role reversal of the traditional malefemale roles" (193). With Mrs. Leland as a professional actress and Arthur as her housekeeper, (albeit one with his own business as well) and with this relation set to continue after the marriage and beyond the end of the story, Gilman apparently effects a gender role reversal with the man more involved in creating and running the private sphere of the home while the woman is left free to continue her career on a public stage. This resolution seems to present in fictional form the turn of the century's new ideology of female liberation and consequent masculine domesticity at work. Supporting her view of this story as role reversal, Elbert cites Margaret Marsh's "Suburban Men and Masculine Domesticity" and refers to the emergence of the "contented suburban father" (Marsh 166) who "even started to share in the onerous household tasks" (Elbert 187). However Marsh's definition of turn of the century "masculine domesticity" is not quite the same as the role reversal Elbert 
wants to find in Gilman's "Her Housekeeper". In her article Marsh specifically states that:

It [masculine domesticity] was not equivalent to feminism. It was not an equal sharing of all household duties. Nor did it extend to the belief that men and women ought to have identical opportunities in the larger society. (166)

In the era when domesticity was clearly linked with women, it was potentially threatening for men and their manhood to be linked with domesticity. Yet as we have seen, for different reasons both masculinists and profeminists thought it necessary for men to become more closely associated with the home and more directly involved in family life, particularly in the care of children. Aware of the anxieties the topic could arouse, Gilman was very careful not to let the version of male domesticity she portrayed in "Her Housekeeper" interfere with Arthur's masculinity. Creating a "Heavily built" male who "lifted" and "set aside" "a pallid young man" (surely a representation of the feminized male) "as if he were an umbrella stand" (149), Gilman highlights Arthur's masculine virtues (as masculinists would refer to them) ensuring that it will not disappear under his tea serving, housekeeping and child-care.

As a result, it is possible to see why Carol Farley Kessler has read Arthur as a "model feminist partner" (59) and Janet Beer has identified a "primary shift in domestic responsibility from the woman to the man" (186). However, in keeping with Marsh's definition, we note that it is the women, the "excellent nursery governess" and maid, employed by Mrs. Leland (148) and the boarding house cook (employed by Arthur) who do all the work. Arthur's only responsibility in this model marriage is to organize the general running of the house, rather than do any of the actual work himself. This continues the role he has been fulfilling from the start of 
the story, although it is only half-way through that Mrs. Leland (and the reader) discovers this fact, when Arthur reveals that he owns and runs the boardinghouse in which she lives so contentedly. This undermines Elbert's argument that this story offers a reversal of traditional male-female roles, or Beer's that it shows a shift in domestic responsibility since in fact the movement is away from the unusual situation where a woman, Mrs. Leland, earns the money to provide for her household, to the more traditional one where women are responsible for their traditional duties (cleaning, cooking and child care) while a man, Arthur Olmstead provides the house itself. Although Mrs. Leland continues her acting career, the implication at the end of the tale is that Arthur becomes responsible for the general housekeeping as part of his normal, boarding-house business. If the cook, maid or the governess were male, or if Mrs. Leland paid Arthur an allowance to run the household, then Elbert's and Beer's argument would be accurate; as it stands, the story is not in fact as revolutionary as it appears.

The balance achieved at the end of "Her Housekeeper" reflects Gilman's assertion that there are in fact three social spheres, not two:

As a matter of fact, there is a "woman's sphere" sharply defined and quite different from his, there is also a "man's sphere", as sharply defined and even more limited, but there remains a common spherethat of humanity, which belongs to both alike. (ManMade, 37)

Gilman implies that sexual roles, which are natural and thus cannot be changed, should be separated from the gender roles that are imposed by society and so can be changed. Thus, while there are areas that can be shared, or duties that can be performed by either (or both) sexes, just as Arthur and Mrs. Leland take some part in caring for Johnny, Gilman's belief in the continued existence of women's spheres and men's spheres and that women should undertake feminine 
roles and men masculine ones, hints that she does not quite approve of the feminine side of Arthur. On the other hand, it is striking that Arthur proves his suitability as husband by his willingness to invite people for tea and to provide it himself. We will find this motif of the male preparing food for others again in "The Cottagette" in which Ford provides a picnic for himself and Malda (although, as discussed below) he has rejected the possibility of following his father into a career as a cook. Such actions by these men in Gilman's fictional world seem to indicate that these men will be good husbands, and offers a positive counterexample to Gilman's point, as summarised by Monika Elbert, that when a man has "low expectations of [his wife], he does not really get much in return"(193). As Gilman explains, the woman cannot be blamed for this situation:

\begin{abstract}
A man ... has his position in the world and in the home, and finds happiness in both. He loves his wife, she meets his requirements as a husband, and he expects nothing more of her. His other requirements he meets in other ways. That she cannot give him this, that, and the other form of companionship . . . is no ground of blame; the world outside does that (Home 226-27).
\end{abstract}

Gilman here presents the relationship between husband and wife in terms of expectations. The husband does not expect his wife to offer more than is necessary to "meet his requirements" which are themselves imagined according to social custom. The assumption is that these may include romantic love and certainly domestic chores but not intellectual companionship. There is thus no disappointment when the wife is not able to share her husband's interests and, more crucially, no thought given to the wife having any interests in the world outside the home on her own account. In fact more usually any such interest is quashed. It is this kind of marriage that Mrs. Leland finds "an imprisonment," and 
which is later categorically dismissed by Arthur as not being a marriage at all in his final assertion "You were never married" (158).

Placing the above passage from Home next to "Her Housekeeper" offers interesting insights into the story as a whole. From the beginning of the story Mrs. Leland has made it clear that she would not give up either her profession or her freedom, nor would she housekeep. Arthur is therefore aware of what to expect and what not to expect from Mrs. Leland as a wife. He does not expect her to do the housekeeping, but nor does he expect to do it either. The actual boardinghousekeeper, who Mrs. Leland finds perfect, is an unnamed woman, whose predecessor was dismissed because Mrs. Leland "did not much like the first housekeeper" (158). In addition to the general staff of the house, Mrs. Leland personally employs a governess and a maid "who didn't much mind where she slept or if she slept at all" (148). These minor characters, who hardly appear in the story, show Gilman's unfeeling practice of simply pushing undesirable jobs onto other usually lower-class women, whom she assumes are happy with their lot. That the household has been arranged to suit Mrs. Leland's taste in one way makes her the most masculine person in the story. At the same time Arthur, as eventual husband, will find some of "his other requirements" and "other forms of companionship" met by his wife, but not the domestic chores, which will simply be passed on to these other largely anonymous women.

What is more interesting is the way Arthur's masculine side is both veiled and revealed by his apparent feminine side. Each time Arthur shows some sort of femininity, such as inviting his friends for tea, Gilman also points out his masculinity by showing his physical strength and habit of taking control of a situation:

"Incidentally wouldn't you be more comfortable on this side of the fire - the light falls better - don't move." And before she realized what he was doing he 
picked her up, chair and all, and put her down softly on the other side, setting the footstool as before, and even daring to place her little feet upon it - but with so businesslike as air that she saw no opening for rebuke. It is difficult matter to object to a man's doing things like that when he doesn't look as if he was doing them (151-52).

Gilman's description of how Arthur uses his power is both amusing and relevant to her concept of the New Man. Arthur picking up the chair with Mrs. Leland still sitting on it and moving her to make her more comfortable amuses. His then carefully placing her feet on the footstool increases the humor, but also shows he is completely in control. This short episode reveals Gilman's New Man as gentle, kind, but still strong: he just uses his strength without offending a woman. Being a strong and independent character, we would expect Mrs. Leland to react against such behavior, and Gilman hints that Mrs. Leland also expects this of herself, but the ease with which Arthur takes command silences and apparently also attracts her. Apparently Gilman prefers her New Man to be in control in some very traditional ways.

However, one important point could be regarded as a moment of conflict between the masculine and feminine expectations. Arthur is more concerned than Mrs. Leland about the care of her son, little Johnny. This, coupled with the way he also takes care of Mrs. Leland herself, makes Arthur more maternal than Mrs. Leland. Although Mrs. Leland has clearly taken proper care of her son-he "does not look like a stage child" (148), we know that she spends little time with him. She may not have kitchen duties to worry about and limit her mental horizon, but her acting profession means she works late and sleeps until nearly lunchtime. The result is that Johnny necessarily spends much of his time with his governess Miss Merton and the maid Alice, a situation close to that described in Women and Economics: 
What he needs far more and receives far less is the companionship, the association, the personal touch, of his father and mother. When the common labors of life are removed from the home, we shall have the time, and perhaps the inclination, to make the personal acquaintance of our children (301).

Mrs. Leland has removed many of the "common labors," the everyday household chores, from her life and so might be presumed to be in a good position herself to bring up a healthy and intelligent boy, rather than a "kitchen-bred" child ("Kitchen- Mindedness" 196). Since she has escaped "the effect of the kitchen ... on the mind" with its "endless repetition," her son enjoys the "progress" that results ("Kitchen- Mindedness" 195). However, Mrs. Leland has her living to earn and her freedom to protect, whereas in contrast Arthur Olmstead always makes time for Johnny and has appropriate amusements for him in his room.

"Her Housekeeper" focuses on how a woman might combine marriage and profession, so including a child is not strictly necessary, but Gilman did so, even though that child scarcely appears in the story. Johnny is brought up by a governess and a maid, and although there is a fleeting mention of kindergarten, these two are his main companions, along with Arthur filling a paternal role. This contrasts sharply with Gilman's ideal of a child's having playmates of the same age:

There would be about one more of one's self, others of the same size and age, in restful, helpful companionship... Think what a passion little children have for playmates of exactly their own age, because in them alone is perfect equality; and then think that the home-kept baby never has such companionship. (Women and Economics 288)

Playmates are therefore of vital importance in children's social education, but Johnny has none. Instead, his governess Miss Merton, as his mother says, "has to go out and play with him-in all weathers" (149). In contrast the house is full of 
people his mother likes and she also has her "little top flat" (148) where she enjoys her privacy. She can eat with the others downstairs if she pleases, but mostly she does not, preferring to take her meal upstairs instead. She is living in the same house as her son, but has isolated herself from the whole household. Freeing herself from housekeeping chores is acceptable in Gilman's eyes, even desirable, as her middle class New Woman should be free from all the drudgery of the responsibilities of home-obstacles to her emancipation, but Mrs. Leland's life seems to imitate that of a stereotypical professional man. She is free from chores, but also from personal involvement in her child's education, very much as a traditional father might be. The example of Mrs. Leland reveals that unless families change how they operate, once women work outside the home, they will not find time for their children, just as once they become involved in housework, they could not find time for themselves.

"Her Housekeeper" is not Gilman's only attempt at presenting an alternative domestic economy. "The Cottagette", written only six months later, also depicts Gilman's aim of involving men as well as women in the struggle for social reform. In the intelligent, successful and admirable Ford Mathews, male readers are offered a model of an enlightened man regarding a creative woman, who earns an independent income, as a desirable companion and a glory of his manhood, not as proof of his lack of manliness. The story's intricate plot explores how a woman might capture a man's heart without succumbing to the traditional female role of domestic angel. Hence Ford's condition that Malda "mustn't cook" (137); to slot into stereotypical roles would be as unattractive to an emancipated man as to a liberated women. The tale, set in an artists' retreat, challenges traditional gender roles. Relationships unfold through the interactions among the three main characters-the narrator, embroidery-designer Malda; her friend, pianist Lois; and fellow resident, writer Ford Mathews. When Malda falls in love with Ford, her understanding of how 
she should act to encourage Ford's interest in her and bring him to propose is influenced by Lois, who is several years older than Malda. Lois enacts the role of an experienced older woman advising a younger friend. Ford Mathews is a writer just beginning to make his reputation and his livelihood, who, as we later learn, has previously needed to accept less fulfilling work as a cook.

Gilman begins her story with Malda, a modern financially independent woman, who enjoys an apparently ideal life, as she shares a holiday "cottagette" at an artists' colony with her friend Lois. Here they are free to spend their time walking, drawing, talking and, in Malda's case, creating the embroidery designs from which she earns her living. Importantly their "cottagette" has no kitchen: the two women take all their meals in a communal dining room and thus are freed from the chore of cooking. As the story begins, Lois acts much as we might expect, that is as a guide and an agent of change in Malda's life. Her character and role is similar to that of other older women in Gilman's fiction at this time, such as Dr. Bellair in The Crux, Mrs. Marroner in "Turned" or Mrs. Gordins in "Making a Change" (all published in 1911), who each help to steer younger woman into becoming New Women. However, when the possibility of marriage arises for Malda, Lois is transformed into a representative of previous generations as she quickly reverts to established beliefs and values. Contrary to our expectations, Lois advises Malda to act like a traditional housewife because, she claims, "What they [men] care for most, after all, is domesticity... what they want is a homemaker" (133). Here Lois, who is Bohemian enough to have gone with her young friend to the artists' colony, now represents the old order of established gender roles that trap women in homes. By presenting the relationship between old and new orders in terms of friendship, rather than defiance or conflict, Gilman is able to reflect the internal confusion felt by many who are caught up in changing times. As Katharine Cockin explains, 
like other women's writing in this period treating the New Woman phenomenon, presents relationships between women (those between older and younger women particularly) as sources of anxiety as well as sources of radical knowledge. Relationships with older women (distantly related but rarely their mothers) promise transformation for the younger generation of women (84).

The relationship with Lois clearly becomes "a source of anxiety" for Malda rather than of "radical knowledge." Lois does not deliver permanent transformation; instead she represents the power of internalized tradition, even for a woman as "rational" (132) and experienced as Lois herself. In this, Lois represents the domestic ideology powerfully advocated in The American Woman's Home (1869) by Gilman's much-respected great aunts, Catherine Beecher (1800-1878) and Harriet Beecher Stowe (1811-1896), whose conservatism seems to have had a lasting effect on Gilman herself. ${ }^{3}$

In spite of doubts, Malda accepts Lois's advice on domesticity and begins to cook. Having begun the story by showing us the benefits of a kitchenless home, Gilman intentionally changes the focus of the story by simply inserting a kitchen into the cottagette. This order of events makes Gilman's presentation of how patriarchal architecture imprisons and isolates women more effective, as readers are faced thereby with role model Malda's loss of freedom. Malda's comment highlights exactly how kitchens can isolate women: "You go in for a minute and you see this thing and that thing and the other thing to be done and your minute is an hour before you know it" (135). No matter how small its size, work always appears needed in a kitchen, as it is the heart of the entire home; a view springing from the assumption that families ought to eat together at home, and so therefore, individual women in domestic kitchens provide the meals that bind families together. Gilman combats this view in Women and Economics by asserting, "Eating is an individual 
function. Cooking is a social function" (240) as she attempts to point out to her readers how easily we overlook the value of cooking to individual homes and to society in general. Household members cannot work without having meals, but the substantial work of preparing those meals prevents the person responsible from doing much else during the day. Properly understood, then, cooking is work that should be recognized as such and removed from individual homes. However, although she eliminates the individual kitchen and substitutes a communal kitchen both in her blue-print for a reformed society in Women and Economics and in the fictional artists' retreat that is the setting of "The Cottagette", Gilman leaves the association of women with domestic labour intact. ${ }^{4}$ We can see this circumstance developing in "The Cottagette" when the kitchen is installed. Malda, a good cook, becomes responsible for producing the meals, and consequently is isolated, but eating remains a social function where everybody sits together to eat the food that Malda has prepared. Indeed precisely because eating is social and thus a way to attract Ford, Lois recommends that Malda show her skill at being a typical domestic wife. However, by showing us the consequences of adding the kitchen to the previously kitchenless cottagette, Gilman inadvertently changes her assertion from "Eating is an individual function. Cooking is a social function" (Women and Economics 240) to "eating is a social function, cooking is an individual function." Of course, in her fully worked out theory of the kitchenless home, Gilman demonstrates that the concept of cooking is altered when it becomes normal practice to eat or fetch meals from communal kitchens run along professional lines. In such idealized conditions day-to-day cooking is taken out of the private sphere and becomes part of the economics of the public sphere. However, in this story, Gilman's concern is not with the paid cook in the communal kitchen, but with the effects of unpaid domestic chores on a talented young woman. Not only does the 
newly added kitchen result in Malda's isolation, but also with this new kitchen come the additional responsibilities of awaiting deliveries and washing dishes. As a result Malda neglects her artistic work, so as not to neglect Ford and so becomes an example of Gertrude Stuart Baillie's view, argued in 1894 that "if a woman should marry, she would be nonetheless an artist, but she would be surrounded by numerous other cares" (293).

While these new domestic obligations restrict Malda's freedom, she remains determined to win over Ford and thus persists with the housework. In effect, Gilman creates a new character for Malda, in contrast to the independent one presented at the beginning of the story, one that now seems close to the helpless, domestic female whose evolution Gilman describes in Women and Economics: "When he became her immediate and all-important environment, she began proportionately to respond to this new influence, and to be modified accordingly" (61-62). Malda is now a woman who has a home, not just a house, and who is sacrificing her own time and pleasure just to keep this home for the man she loves. However, it is not only Ford who drops in: "There were others of course, plenty of them dropping in, but I didn't encourage them, it made so much more work" (135). Paradoxically, Malda and Lois end up with more visitors than they can cope with and have to enlist the help of Lois's mother, who comes to stay; but Malda's isolation still increases. Ford himself seems to enjoy the domestic feeling of the home Malda has created for him, yet because of the housework for which Malda is responsible, the two cannot seem to find time enough to spend together. Malda's new arrangements are more in tune with Gilman's great aunt's views about architectural feminism than her own. Dolores Hayden summarizes Catharine Beecher's view of the home as "above all a space for woman's domestic labor in the service of men and children" (Redesigning 22) so she "had spent her energy heightening gender distinctions and designing an 
ideal single-family home for the Christian wife and mother" (Domestic 184). Yvonne Gaudelius further claims that the aim of Beecher and those who shared her views was to "give women control over the private, domestic spaces of the home" so that women could "gain equal footing with the control that men had in the public sphere" (112). ${ }^{5}$ Beecher argued that if public space is under men's control, domestic space should be under women's control. In marked contrast, Gilman found this control to be so limiting, unproductive, and physically and mentally destructive that she aimed to separate women from domestic duties by professionalizing them, and giving women the same access to the public space that men have.

However, what we see in "The Cottagette" does not quite meet Gilman's aim of professionalizing domestic activities. Malda becomes preoccupied with the kitchen and comes to perceive it as territory not to be shared with anyone else. Malda appears to prove Catherine Beecher right in enjoying her control over this newly-created domestic space, but the arrangement is flawed, as she cannot choose who joins her there. When Lois's mother arrives at the cottagette to help out, Malda finds her an inconvenience as "a new hand in the kitchen," but at the same time thinks to herself, "Ford never seemed to want to wipe dishes, though I often wish he would" (136). In spite of the additional work the kitchen entails, Malda believes she would be content if Ford offered to help her there, yet Ford never takes this opportunity to spend time with her, and so avoids being drawn into this traditionally feminine sphere. Instead he suggests going for a picnic as an alternative social activity they could enjoy together.

Ford's refusal to help in the kitchen raises the question of whether he simply enjoys Malda's sudden domestic conversion, or is unimpressed by the old rules. Though readers may not be clear whether Ford is being criticized for avoiding the kitchen or whether he is right not to join in and so risk being absorbed by 
domestic chores, Gilman soon clarifies: the problem is not who does the work, but the amount of time that the work consumes. Gilman had tackled this topic seven years earlier in The Home (1903) in her usual direct style:

There will be some pathetic protest here that it is a man's duty to help women bear the troubles and difficulties of the home. The woman ardently believes this, and the man too, sometimes. Of all incredible impositions, this is the most astounding... Granting that the care of body is women's special work; the feeding, clothing and cleaning of the world; she should by this time have developed some system of doing it which would make it less of a burden to the man as well as the woman (286-87).

Gilman claims here that women are still responsible for domestic labor: while calling for a new system in terms that make such labor less of a burden to the man may be strategic, the basic assumption that home is the woman's domain remains untouched. The view that women are always responsible for home, while men are never to be so involved, often occurs in Gilman's fiction. ${ }^{6}$ "The Cottagette" is a case in point: the other male visitors may offer to help washing the dishes, but Gilman implies that Malda always refuses. When Ford wants to talk to Malda alone, he takes her out of the house for a walk and comes prepared with a picnic of his own making (136-37). On the other hand, Ford's objection to Malda's new identity reminds her (and readers) of the contentment that existed in the cottagette as it was before the kitchen was added.

This realization, however, raises another question. As my opening quotation from The Home indicates, Gilman claims that husbands consider their wives' supporting themselves unfeminine because such action implies a lack of manliness in themselves as husbands. By analogy, women might well consider husbands' doing housework unmasculine because this signifies a lack of femininity in their capacity as wives. Regardless of their independence, women still consider 
housework as their natural responsibility, and do not want to share it with men, just as men do not want to share with women their wealth producing power. This means that both men and women have a vested interest in maintaining the gendered division of work and responsibility. In her essay "Now We Can Begin" (1920), Crystal Eastman claims that the reason men do not get involved with housework is that they have been socialized to believe that they are incapable of doing it:

Men will not give up their privilege of helplessness without a struggle... It was his mother's fault at the beginning, but even as a boy he was quick to see how a general reputation for being "no good around the house" would serve him throughout life, and half-consciously he began to cultivate that helplessness until to-day it is the despair of feminist wives (239).

This state of affairs comes to appear natural and obvious: each sex internalizes these expectations and each sex assumes that what is so has always been so-men cannot do housework while women have a special talent for it.

While "Her Housekeeper" demonstrates that women perpetuate a traditional state of affairs just as much as men, "The Cottagette" is more subtle since at its conclusion readers find that Ford does not like what domesticity has done to Malda. His not offering to help with domestic chores is an informed refusal and, in Gilman's view, appropriate. Not only was his father a cook "at good wages," but one summer Ford himself also "cooked for a living," but only because he was "hard up" (137). These details betray Gilman's own dislike for cooking, for her routine cooking is an undesirable job, a chore even: Gilman wants readers to understand the effects such work has on those who undertake it and so provides her male hero with past experience that ensures he has personal knowledge of those effects likewise. Ford has no romantic notions about cooking and does not want to endorse the division of labor that places women in the kitchen. His objecting to Malda's being a cook fits 
the image of a New Man, both aware of the damage done by traditional social roles and eager to change them. Ford's objections are based on his recognition of what "this kitchen business" has done to Malda's "beautiful and distinctive art" (137) but we also sense his own distaste for the whole cooking business itself. Here Gilman strategically offers a model for the male acceptance of the New Woman. Guided by Lois, Malda had tried to fit herself into the traditional role of domestic wife; yet now Ford offers her an alternative in the form of a condition for marriage: "You mustn't cook!" (137).

Having created a male character whose father was a cook and who knows how to cook himself, Gilman could easily have concluded the story with an agreement between Ford and Malda to share this domestic chore. However, in Ford's rhetorical question "What would you think of me if I gave up my hard long years of writing for the easy competence of a well-paid cook?" (137), Gilman emphasizes that Ford has no desire to be a cook again. She permits him insight while also feminizing this figure of a New Man, who "was big. Not extra big in pounds and inches, but a man with big view and a grip-with purpose and real power" (132). An emphasis upon Ford's physical appearance echoes careful demonstrations of Arthur Olmstead's physical strength in "Her Housekeeper." Likewise, instead of sharing cooking, the exchange between Ford and Malda at the story's end implies that once married, they will find another communal kitchen. This implication demonstrates Gilman's habit of pushing aspects of life she disliked, such as cooking, cleaning, and other domestic chores out of the main focus of her fiction ${ }^{7}$. Regarding the story in this light, readers see even more clearly how Gilman implicitly supports a role division between men and women, while neglecting the notion that "Participatory democracy begins at home," to borrow Pat Mainardi's phrase (192). We expect Gilman to claim the womanliness as well as manliness of 
earning a living: "The Cottagette" in particular offers Gilman the opportunity of also declaring that cooking and cleaning be considered manly as well as womanly, being part of that third "human" sphere she mentions in Man-Made World (37); but Gilman missed the chance. We could defend Gilman here by saying that far from endorsing the view that men are "no good around the house," as does Eastman (239), she makes the far better point that "Ideas do not change as fast as facts" (Home 325). Yet even so, the patriarchal traditions underlying the idea that running a home is women's duty go unchallenged in both "Her Housekeeper" and "The Cottagette"; nor is it challenged in Gilman's architectural feminism as a whole, where she asserts that "A stronger, wiser, nobler woman must make a better home" (Home 327). Throughout her writing Gilman thus retains women as the sex responsible for the home, even though permitted to act in typically masculine public space as well.

Nonetheless in "The Cottagette," Lois offers traditional, patriarchal advice while Ford provides an alternative. Malda, who appears to have few ideas of her own, as she is easily swayed by Lois or Ford, quietly presents her views, but also sets them aside. Her internalized assumptions quash any slight questioning of Lois's ideas, as does her willingness to follow her advice in the hope of catching Ford: "I had no objection to the work, except that it prevented my doing anything else. And one's hands are not so nice when one cooks and washes dishes, - I need nice hands for my needlework. But if it was a question of pleasing Ford Mathews..." (134). In a manner that recalls the unnamed protagonist of "The Yellow Wall-Paper," Malda's gently worded acceptance of Lois's advice contains both perceptive objection and agreement. The word "question" followed by the ellipsis is key here: they allow us to hear Malda's questioning of Lois's advice, as well as her willingness to follow questionable advice to secure Ford's affections, including ruining her hands for the needlework by which she earns her living and fulfils her creativity. 
Malda focuses on Ford's happiness, while disregarding her own: she assumes she will be happy as long as he is happy. Gilman here portrays Malda as a woman who is in truth dependant on the man in her life, yet at the same time Gilman redeems the situation of the man making the decisions by giving Ford the insight to see that both their lives would be better if Malda gave up her domestic duties. Having at first made this a condition of his marriage proposal, Ford finally gives Malda the option, matching her devotion with his own: "I withdraw the condition. I will love you always, even if you insist on being my cook for life" (138). Readers as well as Ford know Malda's answer even before she utters the words "I don't want to cook" (138) but it is important for the equality of this match that Ford should at least apparently give up his power to make decisions or exact conditions. Accustomed as we are to Gilman's using fiction to present ideal scenarios for social change, we know that this story must end on a positive note, so we are easily led to read Ford as an unconventional male, a New Man like Arthur Olmstead, who is to be praised for going against tradition. In each character, Gilman attempts to show that men can stand outside traditional society and act differently from traditional patriarchal male figures. It is this that allows us to see Ford and Arthur as profeminist men, in Kimmel's terms, and yet as with Arthur, Ford retains enough traditional masculinity to also embody aspects of the masculinist response to feminism and keep at bay any anxieties that Gilman's New Man would be feminized.

However, although the plots and readers' expectations both agree with this conclusion, elements within this story, as in "Her Housekeeper," challenge a completely positive reading of Ford and of "The Cottagette" as a whole. As we consider this story, we become more aware of difference between Malda and Ford. We notice that we have been told that Malda has a minor gift and that Gilman makes her good at a very typical feminine art-designing embroidery. Malda herself doesn't 
believe that her work is important and dismisses it by saying, "Mine wasn't much. I did embroidery and made designs." (132) This artistic skill is her only means of livelihood, which she seems not to value. In contrast Ford as a newspaper man reflects Gilman's own respect for social engagement: his success is signaled by his shift to magazine writing "with books ahead" (131). This man, who has been established from the beginning of the story as someone who appreciates music and art, properly values the work of a woman and requires her to carry it on, if she wants to marry him. It is this that leads Catherine Golden to call Ford Mathews, "Gilman's most liberated New Man" (131) and at first Gilman's ending, with Malda appearing relieved and content, seems to support Golden's view.

However, Gilman's conclusion to the story-Malda's rhetorical question praising Ford-inevitably raises a hint of doubt: "Was there ever a man like this?" (138). If we pause to consider this question carefully, we find that Ford Mathews is similar to other patriarchal figures, particularly Arthur Olmstead, in perhaps the most important respect: he speaks the last word. As a result his apparent final move of letting Malda choose is in fact not really a choice at all, any more than Mrs. Leland is left with room to maneuver and refuse Arthur's proposal of marriage, or even to defend herself against the implication of having lied about her marital status. Although both Arthur and Ford seem to be ideal New Men, content with, if not actively preferring, the prospect of a working wife, both retain the masculine, socially-constructed predilection for power, since here, as elsewhere in her fiction, Gilman makes women's independence reliant upon a man. ${ }^{8}$ The underlying relationship between Ford and Malda, as between Arthur and Mrs. Leland, is disguised because we readers do not want Malda to cook and have been willing Mrs. Leland to marry Arthur. More worryingly perhaps, we, like Malda are willing to accept Ford's estimation of her embroidery work as "quite too good to lose; it is 
beautiful and distinctive art" (137). This assertion is a concise equivalent to Arthur's painstaking step-by-step refutation of Mrs. Leland's objections to marriage, coupled with his avowal of being a longstanding admirer of her acting. But the fact that we agree with these men's conclusions should not lead us to overlook "[t]he transient trade we think evil" (Women and Economics 64) as men and women establish their social and marital roles. We thus collude with society as a whole, as described in Women and Economics, and with Gilman's plots in the two stories considered here: we applaud the marriages-to-be between Arthur and Mrs. Leland and Ford and Malda, seeing them as not just rationally justified but romantically right. By showing us this "trade" in another style, "covered with flowers and incense and all accumulated sentiment" (Women and Economics 63), Gilman allows her readers and perhaps even herself to think it "innocent, lovely, and right"(Women and Economics 63). Yet, no matter how "right" Ford and Arthur appear, we must acknowledge the fact that these men still have the last word concerning Malda and Mrs. Leland's fates and in their respective stories. This in turn means they each maintain their definitive masculine power and status. In short at the end of these tales the husbands have become the "immediate and all-important environment" (Women and Economics 61) for their chosen wives, and the fact that those environments are shown to suit the women concerned should not blind us to the problems that remain within even these happy endings.

\section{Notes}

\footnotetext{
' Gilman's 1910 novel What Diantha Did, serialized in The Forerunner at the same time as the two stories discussed, concerns a housekeeping business run by Diantha, the novel's heroine.

${ }^{2}$ From her own experience, Gilman was very aware of how the public looked down upon divorced women. This reality may account for her choosing to have the heroine of "Her Housekeeper" claim to be a widow. There is some difference of
} 
opinion about Mrs. Leland's actual marital status. Critics such as Kessler and SuttonRamspeck, believe the claim to be a widow is a social fiction, designed to lend some propriety to her son and her own independence of action. Arthur Olmstead's absence part way through the text thus becomes a sleuthing trip during which he ascertains that she has never been married; a fact he then asserts at the end of the story. However, like Polly Wynn Allen, I take Mrs. Leland's claim to be a widow at face value: there is no immediate reason to doubt her word and in fact Gilman makes a point of showing her drawing comparisons between her late husband and Arthur Olmstead when she looks around his rooms in his absence. That absence could be a simple business trip, or indeed one designed to make Mrs. Leland appreciate how much she and more importantly little Johnny miss their friend when he is not there. The statement 'you were never married' thus becomes an assertion that traditional marriage of the kind she experienced with the unknown Mr. Leland is not true marriage at all. That, we are given to understand, she will experience only when married to Arthur.

${ }^{3}$ Gilman regarded herself as having inherited "the Beecher urge to social service" (Living 6) and was conscious of the reputation of her Beecher aunts throughout her life. Of the three sisters-Catharine Beecher, Harriet Beecher Stowe, and Isabelle Beecher Hooker, only the last was actively feminist (see Barbara White, The Beecher Sisters). Gilman's intellectual relationship with Catharine Beecher has been discussed by Monika Elbert in "The Sins of the Mothers and Charlotte Perkins Gilman's Covert Alliance with Catharine Beecher" in Charlotte Perkins Gilman and Her Contemporaries (103-26).

${ }^{4}$ Gilman's discusses the topic of kitchens and domestic labor in various essays and stories as well as in Women and Economics, but always from an essentially middleclass perspective, only rarely acknowledging the role of domestic servants. Even when mentioned, such workers are usually dismissed within a sentence, as is the case with the woman who comes in on Mondays to wash in "The Cottagette" (136) or their work is casually devalued: Ford refers to "the easy competency of a well-paid cook" (137).

${ }^{5}$ For a full discussion of American feminist views on reforming architecture, see Dolores Hayden The Grand Domestic Revolution, which includes a chapter on Gilman. The set-up Mrs. Leland has in "Her Housekeeper" is very close to the "feminist apartment hotel" which Gilman supported, as Hayden discusses The Grand Domestic Revolution pp.189- 195. The fully-fledged version of such an apartment hotel would provide communal child-care facilities as well as the central kitchen and private apartment space so valued by Mrs. Leland. There is no mention of such child-care arrangements in "Her Housekeeper" no doubt partly because Mrs. Leland's son Johnny is the only child in the house, but also, because one of the important aspects that recommends Arthur Olmstead as a husband is his willingness and ability to be involved with Johnny's care and upbringing. Valerie Gill also compares the views of Catharine Beecher and Gilman in her article "Catharine Beecher and Charlotte Perkins Gilman: Architects of Female Power," Journal of American Culture 21:2 (1998): 17-24. Also see Beth Sutton-Ramspeck's discussion of Gilman's presentation of kitchenless homes in some of her other short stories in Raising the Dust: The Literary Housekeeping of Mary Ward, Sarah Grand, and Charlotte Perkins Gilman (Athens: Ohio UP, 2004).

${ }^{6}$ For example, see "Turned" (1911), "Making A Change" (1911), and "Mrs. Merrill's Duties" (1913). 
7 For more information on Gilman's personal experience on cooking and housekeeping

see Living, pp: 78- 89.

8 The Crux is probably the most obvious text in which Gilman's female protagonist is finally given independence through the help of a man, but one might also point to "Mrs. Merrill's Duties" and "Aunt Mary's Pie Plant."

\section{Works Cited}

Adams, Rachel and David Savran, eds. The Masculinity Studies Reader. Oxford: Blackwell, 2002.

Allen, Polly Wynn. Building Domestic Liberty: Charlotte Perkins Gilman's Architectural Feminism. Amherst: The University of Massachusetts Press, 1988.

Baillie, Gertrude Stuart. "Should Professional Women Marry?" 1894. In Keetley and Pettigrew. Vol. 1: 293- 302.

Beecher, Catharine and Harriet Beecher Stowe. The American Woman's Home. 869. Hartford, CT: Stowe-Day Foundation, 1975.

Beer, Janet. Kate Chopin, Edith Wharton and Charlotte Perkins Gilman: Studies in Short Fiction. London: MacMillan \& New York: St. Martin's, 1997.

Cockin, Katharine, "Charlotte Perkins Gilman's "Three Women”: Work, Marriage and the Old(er) Woman." In Rudd and Gough, 74-92.

Connell, R. W. "The History of Masculinity." In Adams and Savran. 245-61.

Davis, Cynthia J. and Denise D. Knight, eds. Charlotte Perkins Gilman and Her Contemporaries. Tuscaloosa: Alabama University Press, 2004.

Eastman, Crystal. "Now We Can Begin." 1920. In Keetley and Pettigrew. Vol. 2: 238 45.

Elbert, Monika M. "Monika M. Elbert." In Knight. 185-96.

---. “The Sins of the Mothers and Charlotte Perkins Gilman's Covert Alliance with Catharine Beecher." In Davis and Knight. 103-126.

Gaudelius, Yvonne. "Kitchenless Houses and Homes: Charlotte Perkins Gilman and the Reform of Architectural Space." In Rudd and Gough. 111-126.

Gill, Valerie. "Catharine Beecher and Charlotte Perkins Gilman: Architects of Female Power." Journal of American Culture $21: 2$ (1998): 17-24.

Gilman, Charlotte Perkins. "Aunt Mary's Pie Plant." Women's Home Companion 6 
(June 1908): 48-49. Rpt. Kessler. 117-28.

---. "Coming Changes in Literature." Forerunner 6 (September 1915): 230-236. Rpt. Knight. 125-32.

--.. "The Cottagette." The Forerunner 1:10 (1910): 1-5. Rpt. Shulman. 130-38.

---. "Her Housekeeper." The Forerunner 1.3 (1910): 2-8. Rpt. Kessler. 147-58.

--.. The Crux: A Novel. 1911. Ed. Jennifer S. Tuttle. Newark: U Delaware P, 2002.

---. "Her Housekeeper." The Forerunner: A Monthly Magazine 1.3 (1910). Rpt. Kessler. 147-58.

--.. The Home: Its Work and Influence. 1903. Ed. Michael S. Kimmel. Boston: Alta Mira, 2002.

---. "Kitchen-Mindedness." The Forerunner: A Monthly Magazine 1.4 (1910): 7-1 1.

--. The Living of Charlotte Perkins Gilman: An Autobiography by Charlotte Perkins Gilman. 1935. Ed. Ann J. Lane. Wisconsin: U of Wisconsin P, 1990.

--. "Making a Change." Forerunner 2:12 (1911): 1- 5. Rpt. Shulman. 182-90.

---. The Man-Made World. Introd. Mary A. Hill. New York: Humanity Books, 2001.

---. "Masculine Literature." Forerunner 1: 5 (1910). Rpt. The Man-Made World. Ch.5.

--.. "Mrs Merrill's Duties." Forerunner 6:3 (1915): 1- 5. Rpt. Shulman. 277-85.

---. "Turned." Forerunner 2: 9 (1911): 1- 6. Rpt. Shulman. 172-81.

---. Women and Economics: A Study of the Economic Relation Between Men and Women as a Factor in Social Evolution. 1898. Eds. Michael Kimmel and Amy Aronson. Berkeley: U of California P, 1998.

Golden, Catherine. "Caging the Beast: The Radical Treatment for 'Excessive Maleness' in Gilman's Fiction." In The Mixed Legacy of Charlotte Perkins Gilman. Eds. Catherine J. Golden and Joanne Schneider Zangrando. Newark: U of Delaware $P$, 2000. 122-34.

Hayden, Dolores. Redesigning the American Dream: The Future of Housing, Work, and Family Life. New York: Norton, 1984.

---. The Grand Domestic Revolution: A History of Feminist Designs for American Homes, Neighborhoods, and Cities. Cambridge, MA: MIT Press, 1981.

Keetley, Dawn and John Pettegrew, eds. Public Women, Public Words: A Documentary History of American Feminism. 3 vols. Madison: $U$ of Wisconsin P, 1997. 
Kessler, Carol Farley. Charlotte Perkins Gilman: Her Progress toward Utopia. Syracuse: Syracuse UP, 1995.

Kimmel, Michael S. Manhood in America: A Cultural History. New York: Free Press, 1996.

---. "Men's Response to Feminism at the Turn of the Century." Gender and Society 1.3 (September, 1987): [Sage Publication].

Knight, Denise D., ed. Charlotte Perkins Gilman: A Study of the Short Fiction. New York: Twayne, 1997.

Mainardi, Pat. "The Politics of Housework: 1968-1970." 1970. In Keetley and Pettigrew. Vol. 3: 162-99.

Marsh, Margaret. "Suburban Men and Masculine Domesticity, 1870- 1915". American Quarterly 40.2 (June, 1988): The John Hopkins University Press.

Rosenberg, Rosalind. Rev. of The Limits of Sisterhood: The Beecher Sisters on Women's Rights and Woman's Sphere, by Jeanne Boydston, Mary Kelley, and Anne Margolis. Journal of American History 76.1 (1989): 261.

Rudd, Jill and Val Gough, eds. Charlotte Perkins Gilman: Optimist Reformer. Iowa City: U of lowa P, 1999.

Shulman, Robert, ed. Charlotte Perkins Gilman: The Yellow Wallpaper and Other Stories. Oxford, UK: Oxford UP, 1995.

Sutton-Ramspeck, Beth. Raising the Dust: The Literary Housekeeping of Mary Ward, Sarah Grand, and Charlotte Perkins Gilman. Athens: Ohio UP, 2004.

White, Barbara. The Beecher Sisters. New Haven: Yale UP, 2003. 